\title{
Compressive Strength and Thermal Conductivity of Fly Ash Geopolymer Concrete Incorporated with Lightweight Aggregate, Expanded Clay Aggregate and Foaming Agent
}

\author{
LIEW YUN MING ${ }^{1 *}$, ANDREI VICTOR SANDU ${ }^{1,2 *}$, HEAH CHENG YONG ${ }^{1,3}$, YUYUN TAJ UNNISA ${ }^{4}$, SITI FATIMAH AZZAHRAN ${ }^{1}$, \\ RIDHO BAYUJ I ${ }^{4 *}$, MOHD MUSTAFA AL BAKRI ABDULLAH ${ }^{1 *}$, PETRICA VIZUREANU ${ }^{1,2}$, KAMARUDIN HUSSIN ${ }^{1,3}$, TAN SOO J IN ${ }^{1,3}$, \\ FOO KAI LOONG ${ }^{5}$ \\ ${ }^{1}$ Center of Excellence Geopolymer and Green Technology (CEGeoGTech), School of Materials Engineering, Universiti Malaysia \\ Perlis (UniMAP), 01000 Kangar, Perlis, Malaysia. \\ ${ }^{2}$ Gheorghe Asachi Technical University of lasi, Faculty of Materials Science and Engineering, 71 D. Mangeron Blvd., 700050, \\ lasi, Romania \\ ${ }^{3}$ Faculty of Engineering Technology, Universiti Malaysia Perlis (UniMAP), 01000 Kangar, Perlis, Malaysia. \\ ${ }^{4}$ Department of Civil Infrastructure Engineering, Institut Teknologi Sepuluh Nopember, Indonesia \\ ${ }^{5}$ Institute of Nano Electronic Engineering (INEE), Universiti Malaysia Perlis (UniMAP), 01000 Kangar, Perlis, Malaysia
}

\begin{abstract}
This paper investigates the effect of incorporation of lightweight aggregate and foam in the preparation of lightweight aggregate geopolymer concrete (LWAGC) and lightweight aggregate foamed geopolymer concrete (LWAFGC). The geopolymer paste was formed by alkali activation of Class $F$ fly ash in mixture of sodium silicate and sodium hydroxide solution. LWAGC was incorporated with expanded clay lightweight aggregate and river sand while hydrogen peroxide was added as foaming agent for LWAFGC. Results showed that LWAGC and LWAFGC achieved an excellent 28-day compressive strength of $60 \mathrm{MPa}$ and 20 $\mathrm{MPa}$, respectively. The bulk densities were $1815 \mathrm{~kg} / \mathrm{m}^{3}$ for $L W A G C$ and $1593 \mathrm{~kg} / \mathrm{m}^{3}$ for LWAFGC. Even so, low thermal conductivity of $0.12 \mathrm{~W} / \mathrm{mK}$ and $0.09 \mathrm{~W} / \mathrm{mK}$ were reported. It was concluded that the joint effect of lightweight aggregate and foam produced geopolymer concrete with good mechanical strength while having excellent thermal insulating properties. The geopolymer concretes possessed high strength-to-density ratio to be regarded as lightweight high-performance structures.
\end{abstract}

Keywords: Lightweight Concrete; Geopolymer; Expanded Clay Aggregate; Foam

Geopolymers are formed by alkali activation of aluminosilicate materials under alkaline condition. The aluminosilicate source rich in Si and Al contents could be waste materials (e.g. ashes [1, 2]) or natural sources (e.g. metakaolin [3], kaolin [4]). On the other hand, high calcium source materials such as slags [5] and class $C$ ashes [6] can also be used as precursor material. The alkaline solution comprises alkali hydroxide and alkali silicates. During the geopolymerization reaction, the alkaline solution dissolves the $\mathrm{Al}^{3+}$ and $\mathrm{Si}^{4+}$ (and $\mathrm{Ca}^{2+}$ ions in case of high calcium raw material) ions from raw material followed by reorganization, gelation and finally hardening to form hard solid. Sodium aluminosilicate hydrate (NASH) is formed in $\mathrm{Si}$ - and Al-rich precursor materials while heterogeneous matrix of NASH, calcium aluminosilicate hydrate (CASH) and/or calcium silicate hydrate (CSH) is formed in geopolymer based on high calcium precursor material [ 7 , 8].

Geopolymers can be added with fine aggregates and coarse aggregates to produce geopolymer concretes. Lightweight concretes are becoming important construction materials owing to their lighter structure which reduces dead load of the structure, ease and less cost in transportation and lessens the cost of construction [9]. Besides, lesser raw materials used in the formation of lightweight concretes also contribute to sustainable characteristic which conserves the environment. The advantages of lightweight concretes are high strength to weight ratio, superior thermal insulation and acoustic properties. They are mostly used in construction of pavements, bridge and roof deck, partition and wall panels, masonry block and bricks and precast concrete units [1013].
Based on American Concrete Institute (ACI) [14], lightweight concretes are categorized into three classes with unit weight less than $1840 \mathrm{~kg} / \mathrm{m}^{3}$. Class I defines structural lightweight concrete with density in the range of $1440-1840 \mathrm{~kg} / \mathrm{m}^{3}$, a minimum compressive strength of $17 \mathrm{MPa}$ and thermal conductivity (TC) between $0.4-0.7 \mathrm{~W} /$ $\mathrm{mK}$. Class II is structural and insulating lightweight concrete with density of $800-1400 \mathrm{~kg} / \mathrm{m}^{3}$, compressive strength of 3.4-17 MPa and TC value of $0.22-0.43$. On the other hand, Class III is insulating lightw eight concrete with low density of $240-800 \mathrm{~kg} / \mathrm{m}^{3}$, low compressive strength within $0.7-3.4$ and low TC value of $0.065-0.22 \mathrm{~W} / \mathrm{mK}$.

Lightweight aggregate concretes are produced by the incorporation of lightweight aggregates. The lightweight aggregates can be natural sources e.g. pumice [9]), recycled materials (e.g. crushed clay bricks [9], glass [15], packaging foam [16] and lightweight block [10]), expanded polystyrene [17] and expanded clay lightweight aggregates [18]. On the other hand, foam concretes with high void space with or without aggregates can be produced with the addition of foam agent (e.g. hydrogen peroxide $[19,20]$, aluminium powder [21] and sodium carbonate [22]) or preformed foam [23]. The presence of lightweight aggregate and foaming agent in geopolymer matrix introduces pores which affect markedly the density, porosity, mechanical strength and thermal conductivity of geopolymers.

The geopolymer foam usually possessed compressive strength below $10 \mathrm{MPa}$ with density within the range of $200-1200 \mathrm{~kg} / \mathrm{m}^{3}$ [24-32]. Even so, the thermal insulation properties were excellent [33]. Feng et al. [34] reported the TC value of as low as $0.07 \mathrm{~W} / \mathrm{mK}$ for fly ash geopolymer foam. In addition, the geopolymer foam produced by Wu

*email:ymliew@unimap.edu.my; sav@tuiasi.ro; bayuaji@ce.its.ac.id; mustafa_albakri@unimap.edu.my 
et al. [35] foamed using hydrogen peroxide has extremely low compressive strength of $0.68-2.23 \mathrm{MPa}$, density of $150-300 \mathrm{~kg} / \mathrm{m}^{3}$ and TC value of $0.0622-0.0852 \mathrm{~W} / \mathrm{mK}$. Based on Sanjayan etal. [36], lightweightgeopolymer foam produced with aluminium powder had compressive strength of $0.9-4.35 \mathrm{MPa}$. According to Zhang et al. [37], the geopolymer foam had compressive strength commonly between 1-10 MPa in the density range of 360 $-1400 \mathrm{~kg} / \mathrm{m}^{3}$. On due course, the geopolymer foam was regarded as Class III lightweight materials based on $\mathrm{ACl}$ owing to its low thermal conductivity and low compressive strength. Geopolymer foam could not be used for structural purposes. The mechanical strength and thermal conductivity of geopolymer foam were significantly affected by the porosity, pore size and density [38].

In term of lightweight aggregate geopolymer concrete, Kupaei et al. [39] reported compressive strength of 9.6 $28.4 \mathrm{MPa}$ with density of $1396-2052 \mathrm{~kg} / \mathrm{m}^{3}$. Posi et al. [16] obtained compressive strength in the range of $5-11 \mathrm{MPa}$ after 28 days for fly ash lightweight geopolymer concrete with recycled foam. The TC values were reported in the range of $0.27-0.35 \mathrm{~W} / \mathrm{mK}$. Besides, according to Islam et al. [40] reported compressive strength of $20-28 \mathrm{MPa}$ and $39-40 \mathrm{MPa}$ for oil palm aggregate lightweight geopolymer concrete and crushed granite lightweight geopolymer concrete, respectively. With expanded clay aggregate, the lightweight geopolymer concrete exhibited compressive strength of $17 \mathrm{MPa}$ after 28 days [18]. In addition, Zaetang et al. [41], fly ash lightweight geopolymer concrete with coal bottom ash aggregate had compressive strength of $5.7-8.6 \mathrm{MPa}$ and TC value of $0.30-0.33 \mathrm{~W} / \mathrm{mK}$. In general, the lightw eight aggregate geopolymer concrete possesses acceptable compressive strength with moderate thermal conductivity. The determining factors of the mechanical and thermal properties of geopolymer concrete were the type and amount of aggregates and pore content of aggregates [42].

The incorporation of both lightweight aggregates and foaming agent in the formation of lightweight aggregate foamed concrete was investigated in this study. Based on previous research [43, 44], lightweight aggregate foamed concrete has been produced using palm oil fuel ash and fly ash with oil palm shell as lightweight aggregate and Sika AER as the foam. The literature of lightweight aggregate foamed concrete was limited. Therefore, in this study, the bulk density, water absorption, porosity, compressive strength and thermal conductivity of lightweight aggregate foamed concrete incorporated with expanded clay aggregate and hydrogen peroxide was analysed and tested. The objectives of this work were to examine the effect of aggregate content and foam content in order to achieve lightweight aggregate foamed concretes with high strength but low thermal conductivity.

\section{Experimental part}

Materials and method

Fly ash, collected from coal power plant of Manjung in Malaysia, was used as the aluminosilicate source. Table 1 tabulates the chemical composition of fly ash as determined using X-ray fluorescent (XRF). Based on ASTM C618 [45], the fly ash is classified as Class $F$ fly ash. Figure 1 shows the SEM micrograph of fly ash particles. The fly ash particle is spherical (microsphere) in shape with glassy surface.

Sodium hydroxide $(\mathrm{NaOH})$ and liquid sodium silicate $\left(\mathrm{Na}_{2} \mathrm{SiO}_{3}\right)$ were used as the alkali activator. The $\mathrm{NaOH}$ pellet is caustic soda with $98 \%$ of purity. The liquid $\mathrm{Na}_{2} \mathrm{SiO}_{3}$ has $\mathrm{SiO}_{2} / \mathrm{Na}_{2} \mathrm{O}$ modulus of 3.2 with viscosity at $20^{\circ} \mathrm{C}$ of $0.40 \mathrm{~Pa} \cdot \mathrm{s}$. The $\mathrm{NaOH} 12 \mathrm{M}$ solution was prepared by
Table 1

CHEMICAL COMPOSITION OF FLY ASH

\begin{tabular}{|l|c|c|}
\hline \multirow{2}{*}{ Compound } & \multicolumn{2}{|c|}{ Weight Percent (\%) } \\
\cline { 2 - 3 } & Fly Ash & ASTM C618 \\
\hline $\mathrm{SiO}_{2}$ & 52.30 & - \\
$\mathrm{Al}_{2} \mathrm{O}_{3}$ & 25.90 & - \\
\hline $\mathrm{Fe}_{2} \mathrm{O}_{3}$ & 10.52 & - \\
\hline $\mathrm{CaO}^{-}$ & 4.90 & - \\
\hline $\mathrm{TiO}_{2}$ & 2.92 & - \\
$\mathrm{K}_{2} \mathrm{O}^{-}$ & 1.81 & - \\
$\mathrm{SO}_{3}$ & 0.06 & $\leq 5$ \\
\hline $\mathrm{LOI}^{-}$ & 1.47 & $\leq 6$ \\
\hline $\mathrm{SiO}_{2}+\mathrm{Al}_{2} \mathrm{O}_{3}+\mathrm{Fe}_{2} \mathrm{O}_{3}$ & 88.72 & $\geq 70$ \\
\hline
\end{tabular}

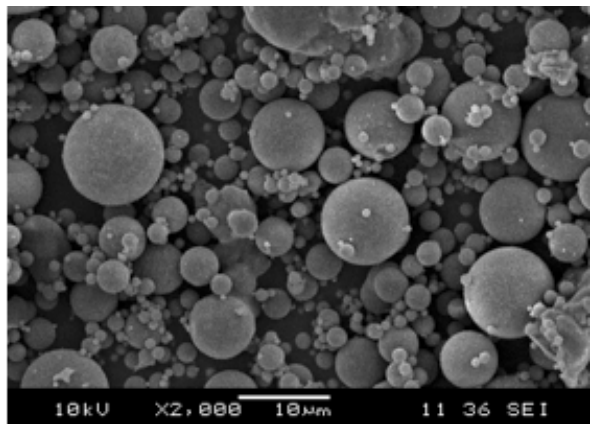

Fig. 1. SEM micrograph of fly ash

dissolving $\mathrm{NaOH}$ pellets in distilled water and allowed to cool down to room temperature before use. Then, the alkali activator solution with $\mathrm{Na}_{2} \mathrm{SiO}_{3} / \mathrm{NaOH}$ ratio of 2.5 was prepared one day prior to mixing to allow for equilibration.

Lightweight expanded clay aggregate (LWA) was used as the coarse aggregate while river sand was used as the fine aggregate in order to produce lightweight aggregate geopolymer concrete (LWAGC) and lightweight aggregate foamed concrete (LWAFGC). The physical properties of LWA and river sand are presented in Table 2. The LWA has spherical shape with rough and closed surface (Figure 2a). The internal structure of LWA consists of well-distributed fine pores and voids (Figure $2 \mathrm{~b}$ ). The ratio of LWA to river sand was fixed at 2:3. In LWAFGC, hydrogen peroxide $\left(\mathrm{H}_{2} \mathrm{O}_{2}\right)$ with $30 \% \mathrm{w} / \mathrm{w}$ was added as the foaming agent.

Table 2

PHYSICAL PROPERTIES OF LWA AND RIVER SAND.

\begin{tabular}{|c|c|c|}
\hline Properties & LWA & River Sand \\
\hline Specific gravity (SSD) & 1.05 & 2.50 \\
\hline Water Absorption (\%) & 17.20 & 1.60 \\
\hline Fineness Modulus & 6.15 & 1.86 \\
\hline
\end{tabular}

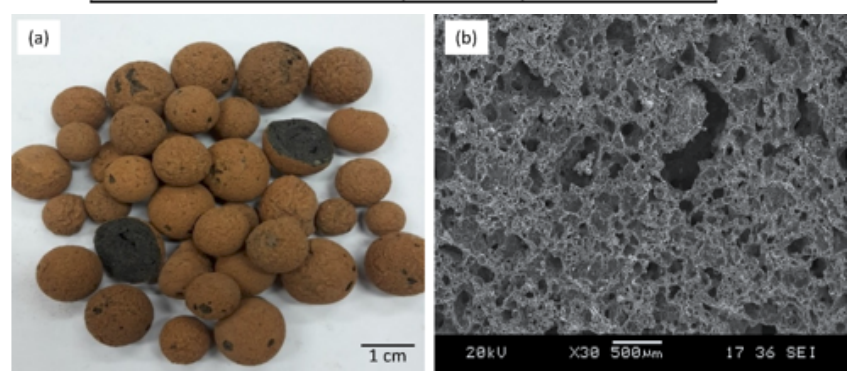

Fig. 2. (a) Physical appearance and (b) porous structure of LWA

\section{Preparation of LWAGC and LWAFGC}

Fly ash and the prepared alkali activator (fly ash/activator ratio of 2.5) were mixed together in a mechanical mixer for 3 minutes to obtain a homogeneous paste. River sand was added into the paste and mixed for another 3 minutes. LWAs were then mixed into the mixture for another 3 minutes. The paste was casted into $100-\mathrm{mm}$ moulds and cured at room temperature $\left(29^{\circ} \mathrm{C}\right)$ for 24 hours followed by $60^{\circ} \mathrm{C}$ in oven for another 24 hours. After curing, the 


\begin{tabular}{|c|c|c|c|c|c|c|}
\hline \multirow{2}{*}{ Sample } & \multicolumn{6}{|c|}{ Weight (g) } \\
\hline & Fly Ash & $\mathrm{Na}_{2} \mathrm{SiO}_{3}$ & $\mathrm{NaOH}$ & LWA & River Sand & $\mathrm{H}_{2} \mathrm{O}_{2}$ \\
\hline LWAGC50 & 1114 & 318 & 127 & 63 & 94 & - \\
\hline LWAGC55 & 1003 & 287 & 115 & $69^{\circ}$ & $103^{-}$ & - \\
\hline LWAGC $60^{\circ}$ & $891^{-}$ & 255 & 102 & 75 & 112 & - \\
\hline LWAGC65 & $780^{\circ}$ & 223 & 89 & 81 & 122 & - \\
\hline LWAGC70 & 669 & $191^{-}$ & 76 & 87 & ${ }^{1} 131^{-}$ & - \\
\hline LWAGC75 & 557 & 159 & 64 & 94 & 140 & - \\
\hline LWAFGC 0.2 & 669 & $191^{-}$ & 76 & 87 & $131^{-}$ & 1.34 \\
\hline LWAFGC 0.4 & 669 & 191 & 76 & 87 & 131 & 2.68 \\
\hline LWAFGC 0.6 & $669^{\circ}$ & 191 & 76 & $87^{\circ}$ & 131 & 4.01 \\
\hline LWAFGC1. & 669 & 191 & 76 & 87 & 131 & 6.69 \\
\hline LWAFGC1.5 & $669^{\circ}$ & 191 & $76^{-}$ & 87 & 131 & 10.04 \\
\hline LWAFGC2.0 & 669 & 191 & 76 & 87 & 131 & 13.38 \\
\hline
\end{tabular}

Table 3

DETAIL OF GEOPOLYMER CONCRETE MIXTURE concrete samples were kept under room temperature until the day of testing.

For LWAGC, The total aggregate content of the paste was varied at $50 \%, 55 \%, 60 \%, 65 \%, 70 \%$ and $75 \%$ by mass. For LWAFGC, the hydrogen peroxide was mixed into the paste for 2 minutes followed by casting and curing process. The dosage of hydrogen peroxide was varied at $0.2 \%, 0.4 \%$, $0.6 \%, 1.0 \%, 1.5 \%$ and $2.0 \%$ based the weight of fly ash. The detail of the concrete mixture is tabulated in Table 3.

\section{Testing and Characterization}

The bulk density of LWAGC and LWAFGC was measured according to BS EN12390-7 [46] by measuring the dimension and mass of geopolymer. Water absorption test and porosity measurement were carried out as accordance with ASTM C642 [47]. The samples were oven-dried at $105^{\circ} \mathrm{C}$ until constant weight is obtained. The oven-dried weight was recorded. Then, the samples were immersed in water for 24 hours. The weights of samples immersed in water and surface dry samples were taken. The water absorption and porosity were calculated using Equations 1 and 2 , respectively.

$$
\begin{gathered}
\text { Water Absorption(\%) }=\frac{W_{a}-W_{d}}{W_{d}} \times 100 \% \\
\text { Porosity }(\%)=\frac{W_{s}-W_{d}}{W_{s}-W_{w}} \times 100 \%
\end{gathered}
$$

where $W_{d}$ is the dry weight, $W$ is the saturated weight in air and $W_{w}^{d}$ is the saturated weight in water. The bulk density, water absorption and porosity of geopolymers were measured after 28 days.

The compressive strength test was performed after 7 and 28 days using Mechanical Tester Shimadzu UH-1000 $\mathrm{KNI}$ as according to ASTM C109 [48]. The geopolymer sample was loaded at constant rate of $5 \mathrm{~mm} / \mathrm{min}$. The average compressive strength was based on three tested samples.

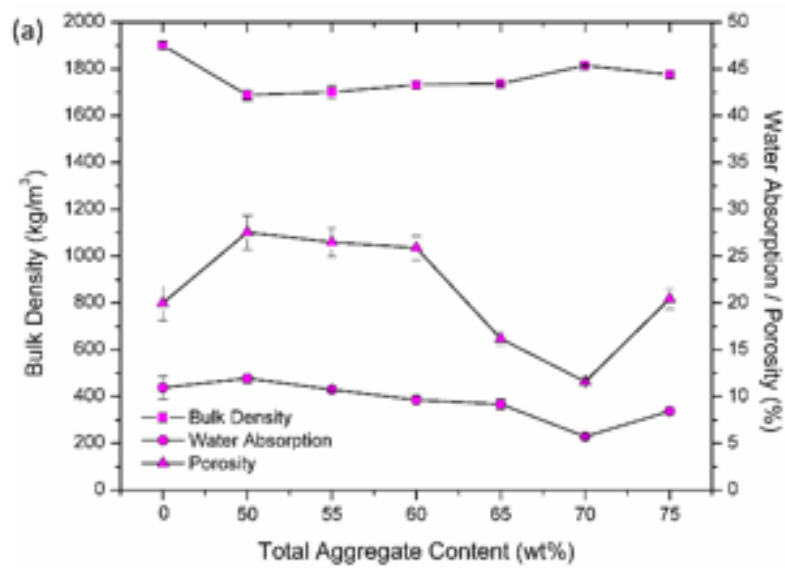

Thermal conductivity was measured after 28 days using the transient heat method with KD2 Pro thermal analyzer. The sample was drilled with diameter $4 \mathrm{~mm}$ drill and length of $60 \mathrm{~mm}$. The RK-1 sensor was coated with thermal grease before inserted into the drilled hole to ensure good thermal contact between sensor and specimen. Measurement was taken at three drilled holes to obtain average reading.

A J SM-6460LA model Scanning Electron Microscopy (JEOL) was used to analyze in the morphology of fly ash, fly ash geopolymers, LWAGC and LWAFGC. Secondary electrons detectors were used for samples imaging. For microstructural analysis of fly ash, fly ash powder was examined. For fly ash geopolymer, LWAGC and LWAFGC, the specimen was fracture surface after compressive strength. The specimen for analysis was coated with palladium before analysis.

\section{Results and discussions}

\section{Bulk Density, Porosity and Water Absorption}

Figure 3 shows the bulk density, water absorption and porosity values of geopolymer, LWAGC and LWAFGC. Fly ash geopolymers had bulk density of $1901 \mathrm{~kg} / \mathrm{m}^{3}$. As already known, incorporation of lightweight aggregates and foaming agents introduce pores in the geopolymer matrix which is expected to reduce the density and hence increase the porosity and water absorption of LWAGC and LWAFGC [49]. The LWAGC exhibited bulk density of 1689 - $1815 \mathrm{~kg} / \mathrm{m}^{3}$. The bulk density reduced by approximately $8 \%$ as compared to fly ash geopolymer without LWA. On the other hand, the addition of foam further lowered the bulk density of LWAFGC to $1426-1593 \mathrm{~kg} / \mathrm{m}^{3}$ (reduced by about $16 \%$ compared to LWAGC). The densities of LWAGC and LWAFGC recorded were still below $1850 \mathrm{~kg} / \mathrm{m}^{3}$ to be regarded as lightweight concrete as per $\mathrm{ACl}$ committee [50].

Fly ash geopolymers exhibited porosity and water absorption of $20 \%$ and $11 \%$, respectively. The high bulk density of fly ash geopolymers led to low water absorption

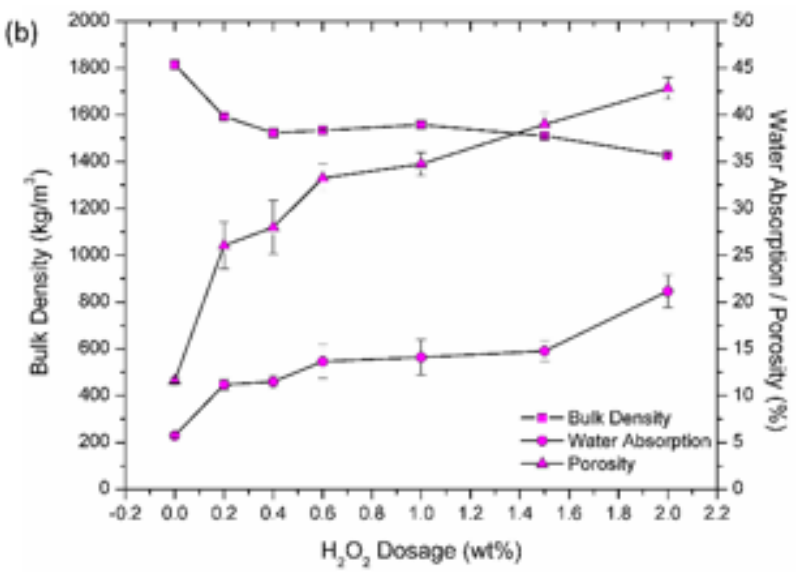

Fig. 3. Bulk density, water absorption and porosity of (a) LWAGC and (b) LWAFGC after 28 days 
and porosity compared to Luna-Galiano et al. [51] who recorded water absorption of $16 \%$ and $26 \%$ for fly ash geopolymers. Increasing total aggregate content (LWAGC50) increased porosity and water absorption. However, decreasing trend with further increasing total aggregate content was observed. The porosity and water absorption of LWAGC were in the range of $11-27 \%$ and 6 - $11 \%$, respectively. Minimum porosity $(6 \%)$ and water absorption (11\%) with highest bulk density $\left(1815 \mathrm{~kg} / \mathrm{m}^{3}\right)$ were recorded for LWAGC70. The water absorption for LWAGC70 was comparable to those obtained by Abdulkareem et al. [52] (10.7\%) with the same proportion of LWA (expanded clay aggregate) and river sand and total aggregate content with respect to the paste. In addition, the bulk density reported in the study by Abdulkareem et al. [53] was also lower $\left(1439 \mathrm{~kg} / \mathrm{m}^{3}\right)$ compared to LWAGC70. This was most probably due to the higher S/L ratio and activator ratio used in this study. The higher $\mathrm{S} / \mathrm{L}$ ratio entailed higher solid content which increases the mass of geopolymers while higher activator ratio induces more silica for geopolymerization reaction to produce denser structure [54].

LWAFGC added with foaming agent had higher porosity $(28-42 \%)$ and water absorption (11 - 21\%). The porosity and water absorption results complied to the bulk density result whereby the lower the bulk density, the higher the porosity and water absorption. Hydrogen peroxide decomposed in alkaline solution releasing oxygen gas which forms voids in the geopolymer mortar. This creates interconnect cell structure (open pores) that allows the penetration of water into LWAFGC. With increasing foam content, the porosity and water absorption increased. This statementhas been well-agreed by other researchers [44].

\section{Compressive Strength}

Figure 4 shows the compressive strength after 7 and 28 days of LWAGC and LWAFGC. The compressive strength increased with ageing day for both LWAGC and LWAFGC [54]. Adding low content of LWA and river sand ( $50 \%$ total aggregate content) caused a reduction of compressive strength by $57 \%$ to $24 \mathrm{MPa}$ after 28 days compared to fly ash geopolymers (56 MPa). The incorporation of weak and porous LWA lowered the density (Figure 3) and thus weaken the compressive strength of LWAGC. The compressive strength increased with increasing total aggregate content and maximized at $60 \mathrm{MPa}$ with $70 \%$ total aggregate content (LWAGC70). Based on Posi et al. [55], increasing LWA aggregate content decreased the compressive strength. It is supposed that the improvement of

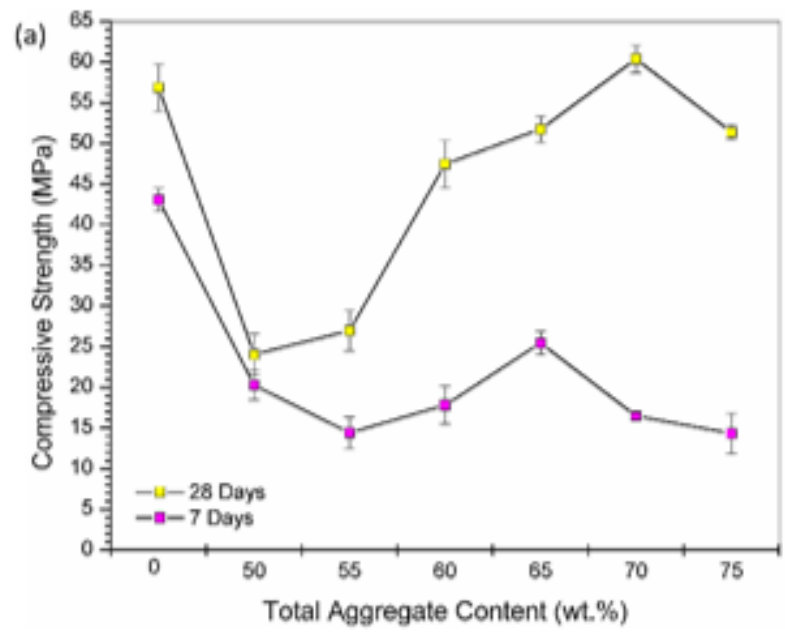

compressive strength of LWAGC is contributed by the strong interfacial transition zone (ITZ) between aggregate and geopolymer matrix as discussed in the later section. The high compressive strength was also due to the high bulk density (Figure 3).

Further increase in the aggregate content deteriorated the compressive strength. However, in this work, the proportion of LWA and river sand was fixed. The LWAGC was produced with increasing total aggregate content indicating more LWA and river sand while lesser binder content in the geopolymer mixture. It was believed that the reducing binder leads to poor bonding between aggregate and matrix (weak ITZ) that caused the degradation of strength for LWAGC75 [44].

The compressive strength of $60 \mathrm{MPa}$ after 28 days with bulk density of $1815 \mathrm{~kg} / \mathrm{m}^{3}$ for LWAGC reported in this work was extremely high. Based on Abdulkareem et al. [52], LWAGC based on fly ash and expanded clay aggregate achieved compressive strength of $18 \mathrm{MPa}$ after 28 days with density of $1438 \mathrm{~kg} / \mathrm{m}^{3}$. Paul \& Labu [56] obtained low compressive strength of $8 \mathrm{MPa}$ after 28 days for LWAGC with expanded clay aggregates. Compressive strength of 3.3 - $19.1 \mathrm{MPa}$ after 28 days with density of $775-1615 \mathrm{~kg} /$ $\mathrm{m}^{3}$ was reported by Yang et al. [57] for LWAGC with expanded clay aggregates. According to Yliniemi et al. [18], fly ash and mine tailings LWAGC with expanded clay aggregates had compressive strength of $17 \mathrm{MPa}$ and density of $1774 \mathrm{~kg} / \mathrm{m}^{3}$. With a comparable density of 1700 - $1792 \mathrm{~kg} / \mathrm{m}^{3}$, Top etal. [58] reported compressive strength of 20 - $55 \mathrm{MPa}$ for LWAGC with basaltic pumice aggregate. Notably, the compressive strength is strongly dependent on the density. The higher density of LWAGC reported in this work had highest compressive strength.

The addition of foaming agent further reduced the compressive strength of LWAFGC (Figure 4b). The compressive strength of LWAFGC was in the range of 14 $20 \mathrm{MPa}$ after 28 days with density range of $1426-1593 \mathrm{~kg} /$ $\mathrm{m}^{3}$. The strength reduction was averagely $72 \%$ with respect to LWAGC70 (Figure 4a). This was expected due to the decrease in bulk density (Figure 3b) as more pores are created by the foaming agent. With increasing content of foaming agent, more oxygen gas was released to form pores, the lower the compressive strength which was supported by Liu et al. [44]. How ever, in their study, lower compressive strength (13.5 MPa after 28 days) was reported for the LWAGC based on palm oil fuel ash and fly ash with oil palm shell as lightweight aggregate even though having the similar density with the LWAGC reported in this study. Besides, the compressive strength of LWAFGC was comparable (4.2 - 23.7 MPa) for the Portland cement

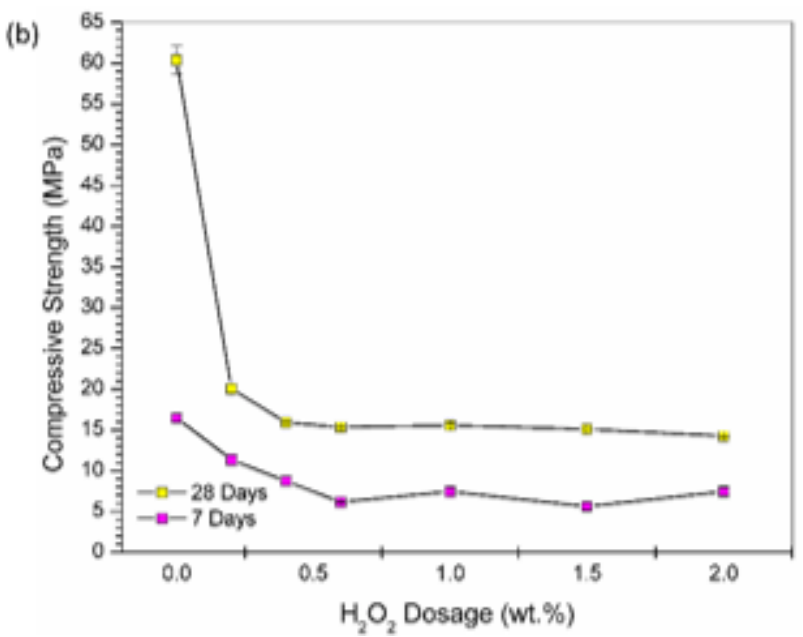

Fig. 4. Compressive strength after 7 and 28 days of (a) LWAGC and (b) LWAFGC. 
(PC) foam concrete incorporated with silica fume, fly ash and slag with similar density range [59].

The LWAGC and LWAFGC obtained in this study could be applied as structural lightweight concrete (Class I) as accordance to $\mathrm{ACl}$ committee [14], aforementioned. Table 5 shows the comparative study of the strength-to-density ratio of geopolymers, LWAGC and LWAFGC. It was worth noting that the fly ash geopolymers, LWAGC and LWAFGC produced in this study have high strength-to-density ratio compared to those obtained by other researchers. A construction material with higher strength-to-density ratio is advantageous for lightweight high-performance structures as itcould reduce the overall cost of construction while increasing the stability.

\section{Thermal Conductivity (TC)}

Thermal conductivity is an important measurement to determine the thermal insulation properties of a material. Low thermal conductivity indicates good thermal insulation. As seen in Figure 5 a, the fly ash geopolymer exhibited TC value of $0.683 \mathrm{~W} / \mathrm{mK}$. Almost similar TC value has been obtained by Subaer \& van Riessen [64]. Generally, geopolymer has $50 \%[34,65,66]$ lower TC than PC concretes with $1.5 \mathrm{~W} / \mathrm{mK}$ [66].

LWA addition in geopolymer was effective to reduce the TC of fly ash geopolymer by $83 \%$ due to the cellular structure of LWA. The TC of LWAGC was in the range of $0.09-0.12 \mathrm{~W} / \mathrm{mK}$ (Figure 5a). Even with a higher bulk density (Figure 3a), the TC value recorded for LWAGC was low compared to those reported by Wongsa et al. [9] in their study on fly ash LWAGC with crushed clay brick ( 0.62 $-0.65 \mathrm{~W} / \mathrm{mK})$ and pumice aggregate $(0.20-0.22 \mathrm{~W} / \mathrm{mK})$. This might most probably due to the higher pore content of expanded clay aggregate compared to crushed clay brick and pumice aggregate. Almost similar TC was obtained by Colangelo et al. [17] for LWAGC with 65\% of expanded polystyrene. However, extremely low compressive strength in the range of $0.32-0.6 \mathrm{MPa}$ was achieved. Higher TC was also concluded by Nematollahi et al. [15] for LWAGC with expanded glass $(0.9 \mathrm{~W} / \mathrm{mK})$, perlite $(1.1 \mathrm{~W} / \mathrm{mK})$ and ceramic microsphere $(1.1 \mathrm{~W} / \mathrm{mK})$ having the similar density range as LWAGC in this study. The TC value was affected

Table 5

COMPARISON OF STRENGTH-TO-DENSITY RATIO OF GEOPOLYMER, LWAGC AND LWAFGC.

\begin{tabular}{|c|c|c|c|c|c|c|c|}
\hline \multirow[t]{2}{*}{ Types } & \multirow[t]{2}{*}{ Precursor Material } & \multirow[t]{2}{*}{ Lightweight Aggregate } & \multirow[t]{2}{*}{ Foam } & \multirow{2}{*}{$\begin{array}{c}\text { Compressive } \\
\text { Strength } \\
\mathrm{MPa}\end{array}$} & \multirow{2}{*}{$\begin{array}{l}\text { Density } \\
\mathrm{kg} \mathrm{m}^{3}\end{array}$} & \multirow[t]{2}{*}{$\begin{array}{l}\text { Strength } \\
/ \\
\text { Density } \\
\text { Ratio } \\
\mathrm{kN} \cdot \mathrm{m} / \mathrm{kg}\end{array}$} & \multirow[t]{2}{*}{ Reference } \\
\hline & & & & & & & \\
\hline \multirow{2}{*}{ Geopolymer } & Fly Ash & - & - & 56.9 & 1901 & 29.9 & This study \\
\hline & Fly Ash & - & - & 30.1 & 1800 & 16.7 & [39] \\
\hline \multirow{7}{*}{$\begin{array}{l}\text { Lightweight } \\
\text { Aggregate } \\
\text { Geopolymer } \\
\text { Concrete }\end{array}$} & Fly Ash & Expanded clay aggregate & - & 60.4 & 1815 & 33.3 & This study \\
\hline & Palm Oil Fuel Ash, Slag & Oil palm shell & - & 28.3 & 1940 & 14.6 & [36] \\
\hline & Fly Ash & Cenosphere & - & 12.8 & 1020 & 12.5 & [56] \\
\hline & Fly Ash & Expanded clay aggregate & - & 18.0 & 1438 & 12.5 & [48] \\
\hline & Slag & Expanded clay aggregate & - & 19.1 & 1615 & 11.8 & [53] \\
\hline & Fly Ash & Recycled lightweight concrete & - & 17.5 & 1500 & 11.7 & [51] \\
\hline & Fly Ash & Crushed clay brick & - & 18.3 & 1749 & 10.5 & [9] \\
\hline \multirow{4}{*}{$\begin{array}{l}\text { Lightweight } \\
\text { Aggregate } \\
\text { Foam } \\
\text { Concrete }\end{array}$} & Palm Oil Fuel Ash, Fly Ash & Oil palm shell & Sika AER & 25.8 & 1700 & 15.2 & [39] \\
\hline & Fly Ash & Expanded clay aggregate & $\mathrm{H}_{2} \mathrm{O}_{2}$ & 20.1 & 1593 & 12.6 & This study \\
\hline & Palm Oil Fuel Ash, Fly Ash & Oil palm shell & Sika AER & 13.5 & 1500 & 9.0 & {$[40]$} \\
\hline & Palm Oil Fuel Ash, Fly Ash & Oil palm shell & Sika AER & 8.3 & 1300 & 6.4 & [40] \\
\hline \multirow{6}{*}{$\begin{array}{c}\text { Foam } \\
\text { Concrete }\end{array}$} & Fly Ash, Slag & - & Preformed foam & 48.0 & 1600 & 30.0 & [23] \\
\hline & Metakaolin & - & Al powder & 14.0 & 1200 & 11.7 & [57] \\
\hline & Fly Ash & - & Preformed foam & 9.0 & 950 & 9.5 & [23] \\
\hline & Metakaolin, Slag & - & $\mathrm{H}_{2} \mathrm{O}_{2}$ & 12.2 & 1340 & 9.1 & [58] \\
\hline & Metakaolin, $\mathrm{NanoSiO}_{2}$ & - & $\mathrm{H}_{2} \mathrm{O}_{2}$ & 5.2 & 690 & 7.5 & [59] \\
\hline & FA. Metakaolin & - & $\mathrm{H}_{2} \mathrm{O}$, & 2.2 & 300 & 7.4 & {$[31]$} \\
\hline
\end{tabular}
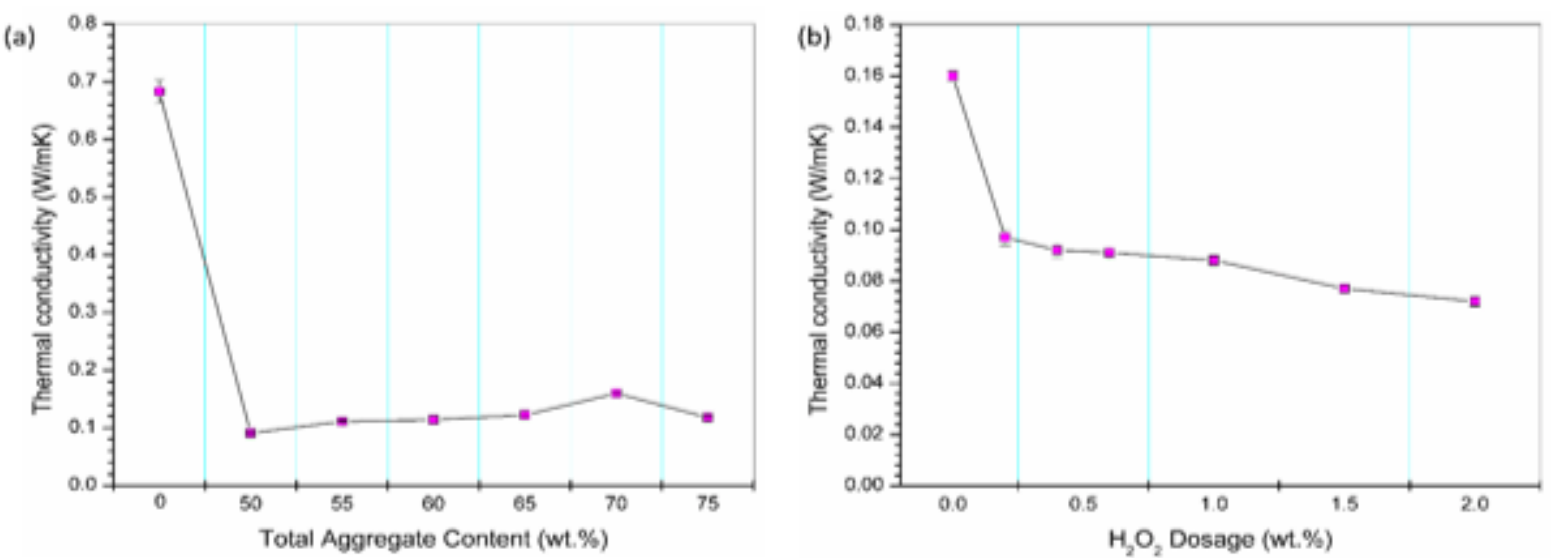

Fig. 5. Thermal conductivity values of (a) LWAGC and (b) LWAFGC after 28 days 


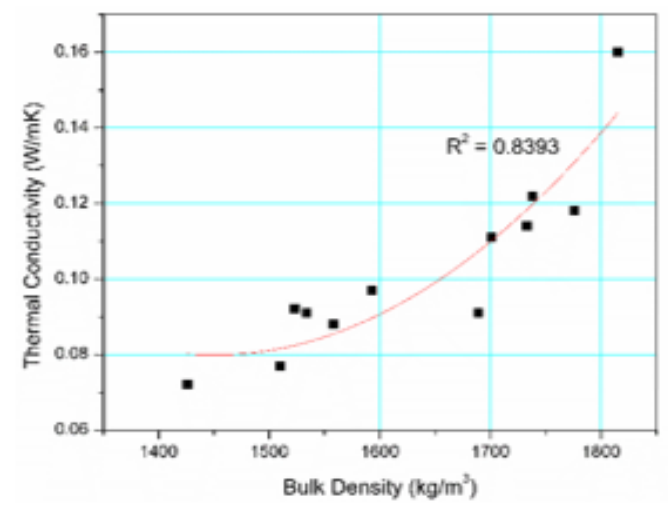

Fig. 6. Relationship between thermal conductivity and bulk density of LWAGC and LWAFGC.
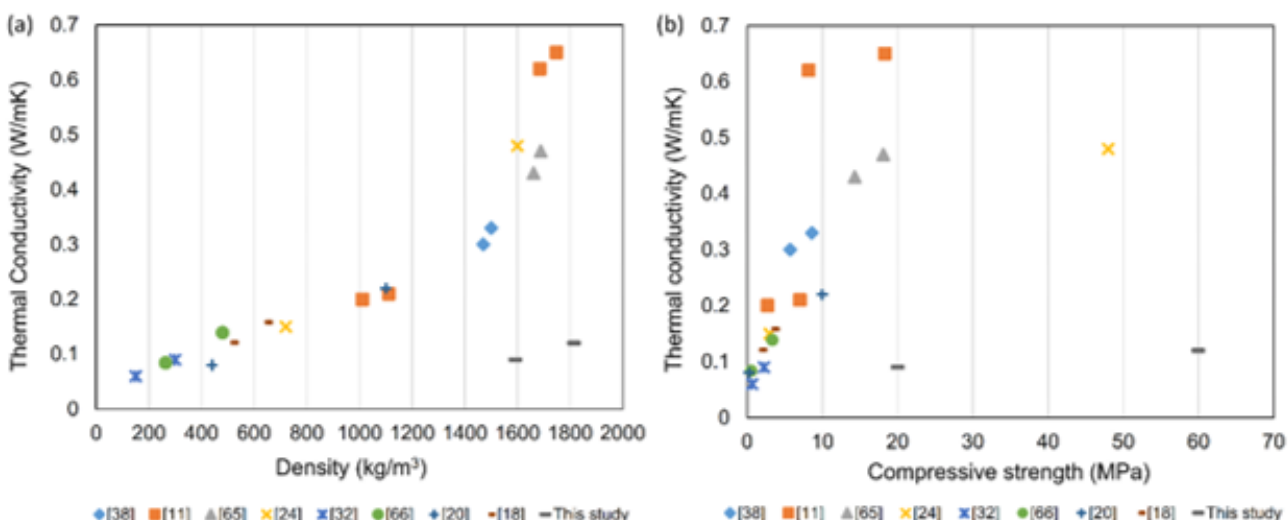

Fig. 7. Comparison of (a) density versus TC and (b) compressive strength versus TC of lightweight concretes obtained in this study with those obtained by others [ 9 , $17,19,23,34,67,68]$

significantly by the pore volume, pore distribution and density [38], as well as other factors such as presence of impurities and/or minerals and the type of aggregate used [64].

The TC of LWAFGC (0.07-0.09 W/mK) further decreased by $46 \%$ with addition of foaming agent (Figure $5 \mathrm{~b}$ ). The TC value was even lower than geopolymer foam without addition of lightweight aggregate. Based on Novais et al. [19], fly ash-metakaolin geopolymer foam possessed TC of $0.08 \mathrm{~W} / \mathrm{mK}$ and $0.22 \mathrm{~W} / \mathrm{mK}$ with density of $440 \mathrm{~kg} / \mathrm{m}^{3}$ and $1100 \mathrm{~kg} / \mathrm{m}^{3}$, respectively. Comparable TC value $(0.06$ $-0.09 \mathrm{~W} / \mathrm{mK}$ ) was reported by Wu et al. [35] on fly ashmetakaolin geopolymer foam which is achieved with the extremely low density of $150-300 \mathrm{~kg} / \mathrm{m}^{3}$. Even so, the geopolymer foam exhibited extremely low compressive strength (0.68 -2.23 MPa) where it can only apply as insulating materials (Class III) based on $\mathrm{ACl}$ committee [14].

The TC values complied with the density (Figure 3) and compressive strength result (Figure 4) whereby lower porosity results in higher density and compressive strength and thus higher TC value [37]. As already known, LWA and foaming agent formed bubbles in the geopolymer matrix which increase the total porosity of the LWAFGC. This caused the lowering TC of porous concrete as air has extremely low TC compared to solid or liquid. The correlation curve as shown in Figure 6 indicated that TC is proportional to density. The correlation coefficient was with $\mathrm{R}^{2}=0.8393$. To recap, the LWAGC and LWAFGC with compressive strength of $60 \mathrm{MPa}$ and $20 \mathrm{MPa}$, respectively and thermal conductivity of $0.12 \mathrm{~W} / \mathrm{mK}$ and $0.09 \mathrm{~W} / \mathrm{mK}$, respectively, could be classified as the Class I lightweight concrete for structural application. At the same time, the low TC values enabled them to be insulating materials. The incorporation of lightweight aggregate and foaming agent achieved TC as low as geopolymer foam with minimal reduction in the compressive strength. With higher bulk density recorded, the thermal conductivity was low (Figure 7).

\section{Microstructural analysis}

Figure 8 reveals the microstructure of fly ash geopolymer which shows smooth and compact matrix. The presence of remnant fly ash particles in conjunction with geopolymer matrix was typical for geopolymers.

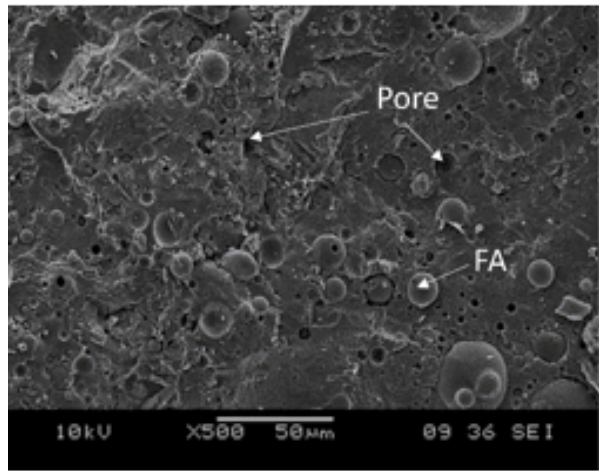

Fig. 8. SEM micrograph of fly ash geopolymer.

As seen in the microstructure of LWAGC (Figure 9), the LWA appeared darker with porous structure while the geopolymer mortar appeared dense and relatively smooth. The pores and voids in LWA caused the reduction of thermal conductivity (Figure 5a). In overall, the indistinct ITZ with no cracking showed good interlocking between LWA and mortar (geopolymer matrix and sand). Besides, no clear pores could be detected in the ITZ of all LWAGC. It seemed that the geopolymer paste has penetrated into the rough surface of $L W A$. This implied that the rough surface of $L W A$ could provide good adhesion between them $[20,54]$ and responsible for the excellent mechanical performance of LWAGC. In the geopolymer mortar, some pores were noticed especially for LWAGC75. Comparatively, the ITZ of LWAG75 was more loosely bound that is believed reduced the compressive strength (Figure $4 a$ ).

Referring to the microstructure of LWAFGC (Figure 10), non-homogeneous and loose structure was seen in the geopolymer matrix. Obvious ITZ can be detected. As compared to LWAGC (non-foamed), the ITZ of LWAFGC appeared porous and loose due to the addition of foaming 

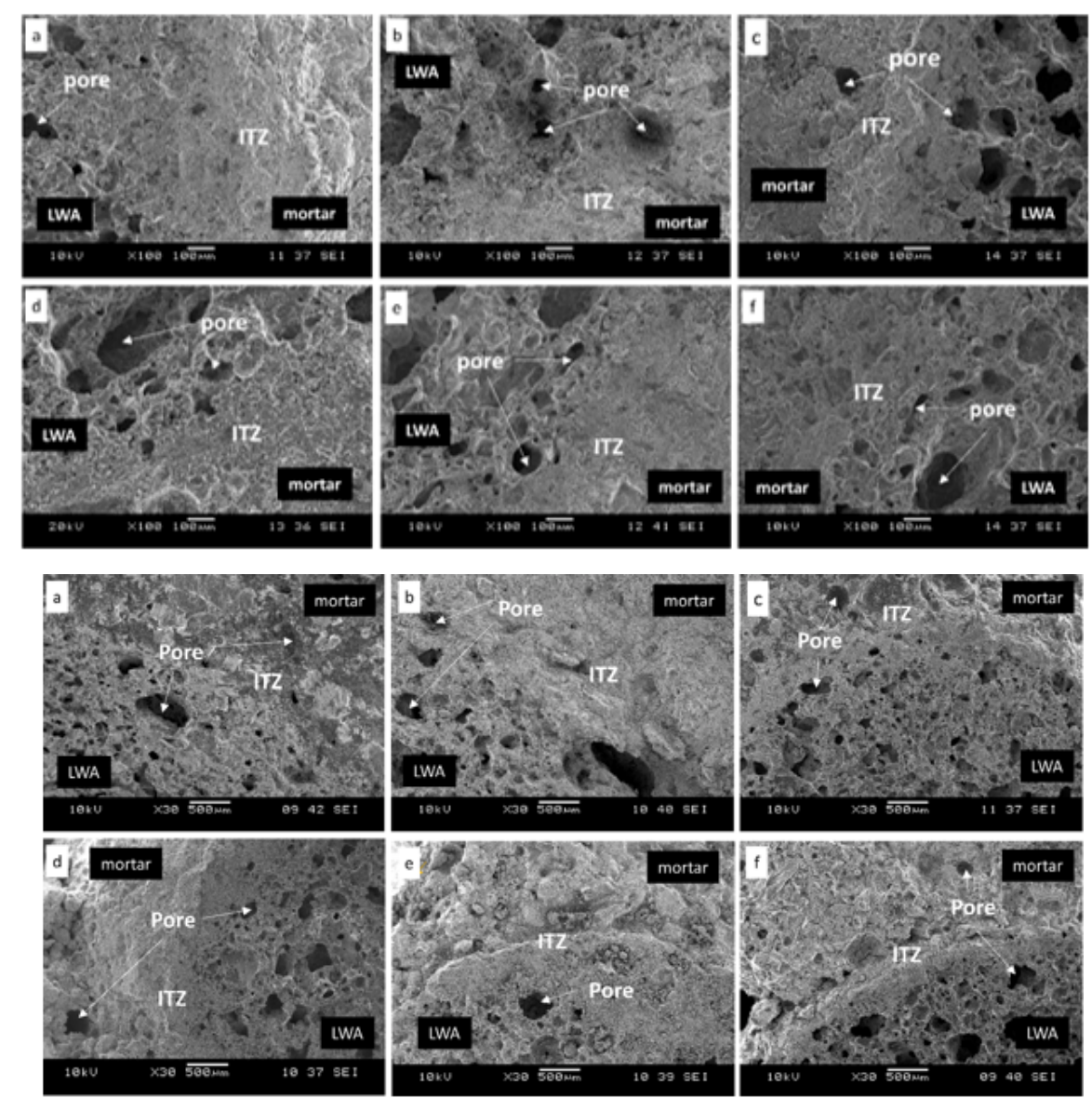

Fig. 9. SEM micrographs of LWAGC with total aggregate content of (a) 50 wt.\%; (b) 55 wt.\%; (c) 60 wt.\%; (d) 65 wt.\%; (e) 70 wt.\%; and (f) 75 wt. $\%$.
Fig. 10. SEM micrographs of LWAFGC with foam content of (a) 0.2 wt.\%; (b) 0.4 wt.\%; (c) 0.6 wt.\%; (d) 1.0 wt.\%; (e) 1.5 wt.\%; and (f) 1.0 wt. $\%$ agent. This indicated a weaker bonding between aggregate and geopolymer matrix which was the significant reason for the strength reduction in LWAFGC. The weak ITZ became stress concentration point to initiate the failure of sample when compressive load is applied. According to Liu etal. [46], the sustainability and distribution of external load of foamed concrete were restricted by high porosity. In their study, large gap of ITZ was observed in LWAGC incorporated with oil palm shell induced by foam [45]. With increasing foam content, the ITZ became increasingly porous and loose with clear dividing line. This consequently led to decreased strength with increasing foam content (Figure 4b).

\section{Conclusions}

This paper investigated the incorporation of expanded clay lightweight aggregate (LWA) and foaming agent in the formation of lightweight aggregate geopolymer concrete (LWAGC) and lightweight aggregate foamed geopolymer concrete (LWAFGC). High-strength LWAGC was achieved with excellent compressive strength of 60 MPa after 28 days with density of $1815 \mathrm{~kg} / \mathrm{m}^{3}$ and TC of $0.12 \mathrm{~W} / \mathrm{mK}$. The microstructure of LWAGC showed strong ITZ between geopolymer matrix and LWA. On the other hand, LWAFGC achieved high strength of $20 \mathrm{MPa}$ after 28 days at low density of $1593 \mathrm{~kg} / \mathrm{m}^{3}$ with low TC of $0.09 \mathrm{~W} /$ $\mathrm{mK}$. Adding foaming agent reduced the strength of LWAFGC. The addition of foaming agent created pores which weaken the bonding between geopolymer matrix and LWA. However, both LWAGC and LWAFGC possessed high strength-to-density ratio which was advantageous as lightweight high-performance structures. Based on ACl, the LWAGC and LWAFGC were categorized as Class I lightw eight concrete for structural purposes. Meanwhile, they can also be regarded as thermal insulating materials with the low TC values reported. Thus, the joint effect of LWA and foaming agent produced low thermal conductivity with low deterioration of compressive strength.
Acknowledgement: The authors would like to express our sincere gratitude for the funding support from Partnership for Research in Geopolymer Concrete (H2020-MSCA-RISE-2015-689857-PRIGeoC) by European Union, Fundamental Research Grant Scheme (FRGS/1/2015/ TK05/UNIMAP/02/2) by Ministry of Education Malaysia and international collaboration with Institut Teknology Sepuluh Nopember, Indonesia (1177/PKS/ITS/2019), by Ministry of Research, Technology and Higher Education.

\section{References}

1.LUHAR, S., CHAUDHARY, S., LUHAR, I., Journal of Building Engineering, 19, 2018, p. 420.

2.FAN, F., Z. LIU, G. XU, PENG, H., CAI, C.S., Construction and Building Materials, 160, 2018, p. 66.

3.SABBATINI, A., VIDAL, L., PETTINARI, C., SOBRADOS, I., ROSSIGNAL, S., Materials and Design, 116, 2017, p. 374.

4.YONG, H.C., HUSSIN, K., ABDULLAH, M.M.A.B., BNHUSSAIN, M., MUSA, L., ISMAIL, K.N., MING L.Y., Romanian J ournal of Materials, 42 , 2012, p. 179.

5.ABDEL-GHANI, N.T., ELSAYED, H.A., ABDELMOIED, S., Housing and Building National Research Center Journal, 14, 2018, p. 159.

6.BAGHERI, A., NAZARI, A., Materials and Design, 54, 2014, p. 483.

7.PILEHVAR, S., CAO, V.D., SZCZOTOK, A.M., CARMONA, M., VALENTINI, L., LANZON, M., RAMIES, R., KJONIKSEN, A-L., Construction and Building Materials, 173, 2018, p. 28.

8.HUSEIEN, G.F., ISMAIL, M., KHALID, N.H.A., HUSSIN, M.W., MIRZA, J., Alexandria Engineering J ournal, 57, 2018, p. 3375.

9.WONGSA, A., SATA, V., NUAKLONG, P., CHINDAPRASIRT, P., Construction and Building Materials, 188, 2018, p. 1025.

10.POSI, P., TEERACHANWIT, C., TANUTONG, C., LIMKAMOLTIP, S., LERTNIMOOLCHAI, S., SATA, V., CHINDAPRASIRT, P., Materials and Design, 52, 2013, p. 580.

11.MEDRI, V., PAPA, E., MAZZOCCHI, M., LAGHI, L., MORGANTI, M., FRANCISCONI, J., LANDI, E., Materials and Design, 85, 2015, p. 266. 12.SARI, D., PASAMEHMETOGLU, A.G., Cement and Concrete Research, 35, 2005, p. 936.

13.PUSKAS, A., CORBU, O., KOLLO, S.A., 16th Edition National Technical-Scientific Conference Modern Technologies for the 3rd 
Millenium, S. Nistor and G.A. Popoviciu, Editors. 2017, Editografica: Oradea, Romania.

14.Building Code Requirements for Structural Concrete (ACl 318M11) and Commentary. 2011: Farmington Hills, Michigan.

15.NEMATOLLAHI, B., RANADE, R., SANJ AYAN, J., RAMAKRISHNAN, S., Archives of Civil and Mechanical Engineering, 17, 2017, p. 55.

16.POSI, P., RIDTIRUD, C., EKVONG, C., CHAMMANEE, D., JANTHOWONG, K., CHINDAPRASIRT, P., Construction and Building Materials, 94, 2015, p. 408.

17.COLANGELO, F., ROVIELLO, G., RICCIOTTI, L., FERRANDIZ-MAS, V., MESSINA, F., FERONE, C., TARALLO, O., CIOFFI, R., CHEESEMAN, C.R., Cement and Concrete Composites, 86, 2018, p. 266.

18.YLINIEMI, PAIVA, FERREIRA, TIAINEN, ILLIKAINEN, Construction and Building Materials, 131, 2017, p. 784.

19.NOVAIS, R.M., ASCENSAO, G., BURUBERRI, L.H., SENFF, L., LABRINCHA, J.A., Materials and Design, 108, 2016, p. 551 - 559.

20.PETLITCKAIA, S., POULESQUEN, A., Ceramics International, 45, 2019, p. 1322.

21.ZHU, W., RAO, X.H., LIU, Y., YANG, E-H., J ournal of Cleaner Production, 177, 2018, p. 775.

22.ALGHAMDI, H., NEITHALATH, N., Materials Today Communications, 17, 2018, p..

23.ZHANG, Z., PROVIS, J .L., REID, A., WANG, H., Cement and Concrete Composites, 62, 2015, p. 97.

24.MASI, G., RICKARD, W.D.A., VICKERS, L., BIGNOZZI, M.C., VAN RIESSEN, A., Ceramics International, 40, 2014, p. 13891.

25.DUCMAN, V., KORAT, L., Materials Characterization, 113, 2016, p. 207.

26.NOVAIS, R.M., BURUBERRI, L.H., ASCENSAO, G., SEABRA, M.P., LABRINCHA, J.A., J ournal of Cleaner Production, 119, 2016, p. 99.

27.HAJ IMOHAMMADI, A., NGO, T., MENDIS, P., SANJ AYAN, J., Materials \& Design, 120, 2017, p. 255.

28.BAI, C., COLOMBO, P., Ceramics International, 43, 2017, p. 2267. 29.BURDUHOS NERGIS, D.D., ABDULLAH, M.M.A.B., VIZUREANU, P., European Journal of Materials Science, 2, no. 4, 2017, p. 111.

30.BURDUHOS NERGIS, D.D., VIZUREANU, P., CORBU, O., Rev. Chim.(Bucharest), 70, no. 4, 2019, p. 1262.

31.BURDUHOS NERGIS, D.D., ABDULLAH, M.M.A.B., VIZUREANU, P., MOHD TAHIR, M.F., IOP Conference Series: Materials Science and Engineering, 374, 2018, art. 012019

32.YAHYA, Z., ABDULLAH, M.M.A.B., MOHD RAMLI, N., BURDUHOS NERGIS, D.D., ABD RAZAK, R. IOP Conference Series: Materials Science and Engineering, 374, 2018, art. 012068.

33.MUGAHED AMRAN, Y.H., FARZADNIA, N., ABANG ALI, A.A., Construction and Building Materials, 101, 2015, p. 990.

34.FENG, J., ZHANG, R., GONG, L., LI, Y., CAO, W. , CHENG, X., Materials and Design, 65, 2015, p. 529.

35.WU, J., ZHANG, Z., ZHANG, Y., LI, D., Construction and Building Materials, 168, 2018, p. 771.

36.SANJAYAN, J.G., NAZARI, A., CHEN, L., NGUYEN, G.H., Construction and Building Materials, 79, 2015, p. 236.

37.ZHANG, Z., PROVIS, J.L., REID, A., WANG, H., Construction and Building Materials, 56, 2014, p. 113.

38.NGUYEN, T.T., BUI, H.H., NGO, T.D., NGUYEN, G.D., KREHER, M.U., DARVE, F., Engineering Fracture Mechanics, 209, 2019, p. 228.

39.KUPAEI, R.H., ALENGARAM, U.J., JUMAAT, M.Z.B., NIKRAZ, H., Construction and Building Materials, 43, 2013, p. 490.

40.ISLAM, A., ALENGARAM, U.J ., JUMAAT, M.Z., GHAZALI, N.B., YUSOFF, S., BASHAR, I.I., Construction and Building Materials, 152, 2017, p. 964.
41.ZAETANG, Y., WONGSA, A., SATA, V., CHINDAPRASIRT, P., Construction and Building Materials, 96, 2015, p. 289.

42.ZORIC, D., LAZAR, D., RUDIC, O., RADEKA, M., RANOGAJEC, J., HIRSENBERGER, H., Journal of Thermal Analysis and Calorimetry, 110, 2012, p. 489.

43.LIU, M.Y.J., ALENGARAM, U.J., JUMAAT, M.Z., MO, K.H., Energy and Buildings, 72, 2014, p. 238.

44.LIU, M.Y.J ., ALENGARAM, U.J ., SANTHANAM, M., JUMAAT, M.Z., MO, K.H., lightweight Construction and Building Materials, 120, 2016, p. 112.

45.**8 ASTM C618-12a, Standard Specification for Coal Fly Ash and Raw or Calcined Natural Pozzolan for Use in Concrete. 2012, ASTM International: West Conshohocken.

46.*** BSEN 12390-7. Testing hardened concrete. Density of hardened concrete. 2000: London: British Standards.

47.***ASTM C642-13, Standard Test Method for Density, Absorption, and Voids in Hardened Concrete. 2013, ASTM International.

48. ***ASTM C109/C109-05. Standard test method for compressive strength of hydraulic cement mortars (Using 2-in. or [50mm] cube specimens). ASTM International. 2008.

49.KUMARA, N.V., ARUNKUMARA, C., SENTHIL, S.S., Materials Today: Proceedings, 5, 2017, p. 8753.

$50 . * * * \mathrm{ACl} 213 \mathrm{R}-14$. Guide for Structural Lightweight-Aggregate Concrete. 2014, American Concrete Institute.

51.LUNA-GALIANO, Y., CORNEJ O, A., LEIVA, C., VILCHES, L.F., FERNANDEZ-PEREIRA, C., Materiales de Construccion, 65, 2015, e059. 52.ABDULKAREEM, O.A., BAKRI, A.M.M.A., KAMARUDIN, H., NIZAR, I.K., SAIF, A.A., Construction and Building Materials, 50, 2014, p. 377. 53.YUN-MING, L., CHENG-YONG, H., BAKRI, M.M.A., HUSSIN, K., Progress in Materials Science, 83, 2016, p. 595.

54.ARIOZ, E., ARIOZ, O., KOCKAR, O.M., International Journal of Chemical Engineering and Applications, 4, 2013, p. 423.

55.POSI, P., THONGJAPO, P., THAMULTREE, N., BOONTEE, P., KASEMSIRI, P., CHINDAPRASIRT, P., Construction and Building Materials, 127, 2016, p. 450.

56.PAUL, S., BABU, G., Transactionso on Engineering and Sciences, 2, 2014, p. 33.

57.YANG, K., SONG, J., LEE, J., J ournal of Materials Structure, 43, 2010, p. 403.

58.TOP, S., VAPUR, H., Journal of Molecular Structure, 1163, 2018, p. 10.

59.PAN, Z., HIROMI, F., TIONGHUAN, W., J ournal of Wuhan University of Technology - Materials Science Edition 22, 2, 2007, p. 295.

60.WU, H.C., SUN, P., Construction and Building Materials, 21, 2007, p. 211.

61.AGUILAR, R.A., DIAZ, O.B., GARCIA, J.I.E., Construction and Building Materials, 24, 2010, p. 1166.

62.KORAT, L., DUCMAN, V., Cement and Concrete Composites, 80, 2017, p. 168.

63.PALMERO, P., FORMIA, A., ANTONACI, P., BRINI, S., TULLIANI, J.M., Ceramics International, 41, 2015, p. 12967.

64.SUBAER, VAN RIESSEN, A., J ournal of Materials Science, 42, 2007, p. 3117.

65.SAIKRASOON, A., JIEMSIRILERS, S., LAORATANAKUL, P., Key Engineering Materials, 659, 2015, p. 106.

66.FONGANG, R.T.T., PEMNDJE, J., LEMOUGNA, P.N., MELO, U.C., NANSEU, C.P., NAIT-ALI, B., KAMSEU, E., LEONELLI, C., Energy and Buildings, 107, 2015, p. 113.

67.W ONGSA, A., ZAETANG, Y., SATA, V., CHINDAPRASIRT, P., Construction and Building Materials, 111, 2016, p. 637. 68.SAMSON, G., CYR, M., GAO, X.X., Construction and Building Materials, 157, 2017, p. 982-993.

Manuscript received: 12.11 .2019 